\title{
Scrap Processor Struck by Wrench and Dies after Makeshift Torque System Fails
}

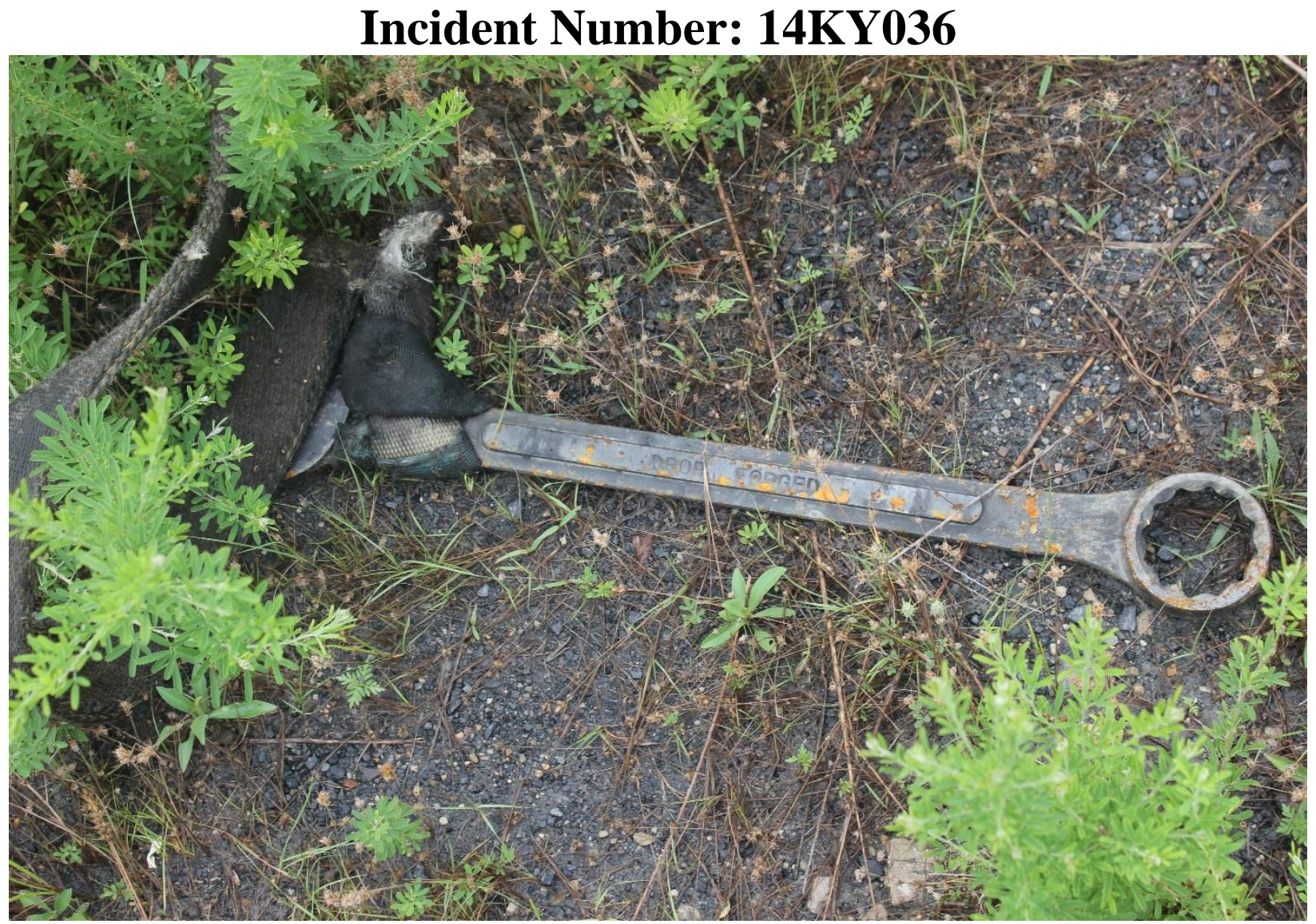

Photo courtesy of KY OSH

Kentucky Fatality Assessment and Control Evaluation Program Kentucky Injury Prevention and Research Center 333 Waller Avenue Suite 242

Lexington, Kentucky 40504

Phone: 859-323-2981

Fax: 859-257-3909

www.kiprc.uky.edu

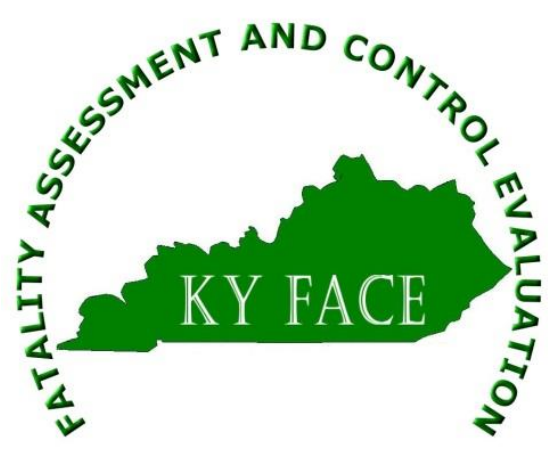




\section{Kentucky Fatality Assessment and Control Evaluation (FACE) Program Incident Number: 14KY036 \\ Release Date: March 5, 2015 \\ Subject: Scrap Processor Struck by Wrench and Dies after Makeshift Torque System Fails}

\section{Introduction}

On June 30, 2014, a 42-year-old scrap processor was instructed by his supervisor to salvage the main bolts on a locomotive flywheel that was being scrapped, so the normal procedure of removing them with a torch was replaced by the following method: To increase tension, the scrap processor wrapped one end of a large $48 \mathrm{~mm}$ wrench with a makeshift sling that was tied at the other end to an excavator grapple. The scrap processor fit the wrench on the bolt and an excavator operator applied tension to the sling on the excavator. Once the bolt was loosened, the scrap processor signaled the excavator operator to lower the tension, after which the scrap processor moved the wrench to the next bolt.

After successfully removing 40 bolts using this method, the scrap processor placed the wrench on the next bolt and signaled the excavator operator to apply tension. While tension was applied, the victim grabbed the sling and leaned over to observe the bolt. The wrench slipped off the bolt, shot out and struck the victim on the right side of his head causing him to fall 6 feet to the ground, striking several pieces of scrap metal. Emergency Medical Services were called at 11:40 am. They arrived approximately 15 minutes later and the victim was flown to a Level 4 trauma center. Physicians placed the victim into an induced coma. The victim succumbed to his injuries 13 days later and died.

To prevent future occurrences of similar incidents, the following recommendations have been made:

Recommendation No. 1: Employers should ensure employees use appropriate tools for the required job.

Recommendation No. 2: Employers should ensure employees use appropriate personal protective equipment such as hard hats, and fall protection.

Recommendation No 3: Employers should require guarding or ensure that fall protection is utilized when employees are working four feet or more above ground.

Recommendation No 4: Employers should develop and implement a comprehensive safety and health program that includes an operating procedure for removing bolts on a locomotive flywheel. 


\section{Employer}

The employer was established in 2007 and located in another state. The employer provides ferrous and nonferrous metal recycling. The company employs 20 workers.

\section{Written Safety Programs and Training}

The employer did not furnish any written safety programs or training records.

\section{$\underline{\text { Victim }}$}

The victim was a 42-year-old, married father who had been employed directly with the company for five years prior to the fatality. His occupation was a scrap processor. He was a high school graduate, who also had attended college but received no degree.

\section{Incident Scene}

The scene was a mining site with a railroad traversing it. The locomotive that was being scrapped was located on the railway along with several other locomotives.

\section{$\underline{\text { Weather }}$}

June 30, 2014 was a mostly cloudy day with temperatures ranging from 77 to 83 degrees Fahrenheit. Weather was not considered a factor in this fatality.

\section{Investigation}

The Kentucky Fatality Assessment and Control Evaluation Program was notified by the Kentucky Labor Cabinet of an occupational fatality involving a scrap processor.

On June 30, 2014, a 42-year-old scrap processor was removing the main bolts on a locomotive flywheel. The victim was instructed by his direct supervisor to salvage bolts, so he could not use the normal procedure of removing them with a torch. No hydraulic wrench was available, so to increase tension, the scrap processor wrapped one end of a large $48 \mathrm{~mm}$ wrench with a Haul Master double polyester sling with a vertical lifting capacity of 6,400 lbs. The sling was tied at the other end to an excavator grapple. The scrap processor fit the wrench on the bolt and an excavator operator applied tension to the sling on the excavator. Once the bolt was loosened, the scrap processor signaled the excavator operator to lower the tension, after which the scrap processor moved the wrench to the next bolt. The employees had removed 40 bolts in this manner prior to the incident. The original guardrails on the locomotive had been removed prior to starting the work, leaving an exposure for falls for the employee on the locomotive.

The scrap processor placed the wrench on the bolt and signaled the excavator operator to apply tension. While tension was applied, the victim grabbed the sling and leaned over to observe the bolt. The wrench slipped off the bolt, shot out and struck the victim on the right side of his head causing him to fall 6 feet to the ground, striking several pieces of scrap metal. Emergency 
Medical Services was called at 11:40 am. They arrived approximately 15 minutes later and the victim was flown to a Level 4 trauma center for treatment. Physicians placed the victim in an induced coma. The victim succumbed to his injuries 13 days later and died.

\section{Cause of Death}

The cause of death was depressed skull fracture and subarachnoid hemorrhage, severe traumatic brain injury.

\section{$\underline{\text { Recommendations and Discussions }}$}

Recommendation No. 1: Employers should ensure employees use appropriate tools for the required job. ${ }^{1}$

When the employer required bolts to be salvaged, a hydraulic wrench should have been provided.

Recommendation No. 2: Employers should ensure employees use appropriate personal protective equipment such as hard hats, and fall protection. ${ }^{2}$

The employees were provided hard hats and safety glasses for this job. Hard hats were required on site but were not being worn. The onsite supervisor did not enforce the use of the PPE at the worksite. A hard hat may have deflected the impact of the wrench on the victim's head when it struck him.

Recommendation No 3: Employers should require guarding or ensure that fall protection is utilized when employees are working four feet or more above ground. ${ }^{3}$

The guardrail had been removed prior to work being performed, and the employees were not using fall protection while working six feet above the ground. Had the railing and fall protection been in place, it could have prevented the victim falling onto scrap metal pieces that were on the ground, possibly reducing his injuries.

Recommendation No 4: Employers should develop and implement a comprehensive safety and health program that includes an operating procedure for removing bolts on a locomotive flywheel.

The company's safety and health program was requested by KY OSH but not furnished to the $\mathrm{KY} \mathrm{OSH}$ inspector, leaving the company vulnerable to safety and health citations and fines. KY OSH requires that all businesses provide a safe work environment for their employees and establish and implement comprehensive safety and health programs and policies to instruct employees on how to work safely. 


\section{Keywords}

Construction falls

Open walkways

Guarding openings

Worker fatality

Worker safety

OSHA

Occupational safety

\section{References}

${ }^{1}$ Hydraulic Torque Wrench Operation. Youtube.com. Uploaded by user WindTechTv. [www.youtube.com/watch?v=jOk6ZYggc4g] Date Accessed: December, 2014.

${ }^{2}$ General requirements of eye or face protection. 29 CFR 1910.133(a)(1) and (a)(2) [https://www.osha.gov/pls/oshaweb/owadisp.show_document?p_table=STANDARDS\&p _id=9778] Accessed: December, 2014.

And

General requirements for head protection. 29 CFR 1910.135 (a).

[https://www.osha.gov/pls/oshaweb/owadisp.show_document?p_table=STANDARDS\&p _id=9785] Accessed: December, 2014.

${ }^{3}$ Protection of open-sided floors, platforms and runways. 29 CFR 1910.23(c)(1).

[https://www.osha.gov/pls/oshaweb/owadisp.show_document?p_table=STANDARDS\&p _id=9715] Accessed: January, 2015.

And

Duty to have fall protection. 29 CFR 1926.501(b).

[http://www.law.cornell.edu/cfr/text/29/1926.501] Accessed: January, 2015.

\section{Acknowledgements}

The Kentucky FACE program would like to thank the funeral home, EMS and Kentucky OSHA for their assistance with this report.

The Kentucky Fatality Assessment \& Control Evaluation Program (FACE) is funded by grant 2U60OH008483-10 from the Centers for Disease Control and Prevention and the National Institute for Occupational Safety and Health. The purpose of FACE is to aid in the research and prevention of occupational fatalities by evaluating events leading to, during, and after a work related fatality. Recommendations are made to help employers and employees have a safer work environment. For more information about FACE and KIPRC, please visit our website: www.kiprc.uky.edu 


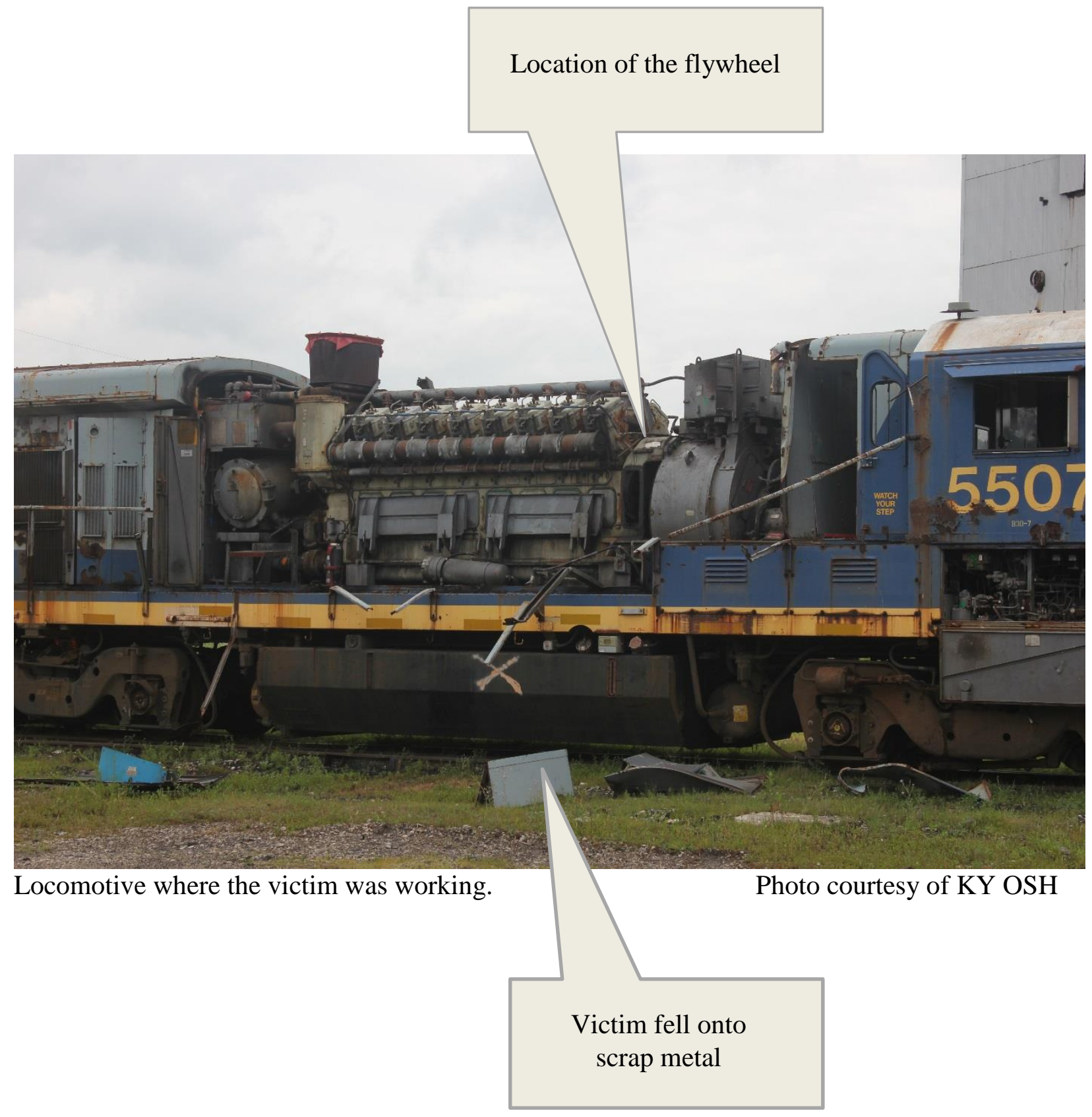




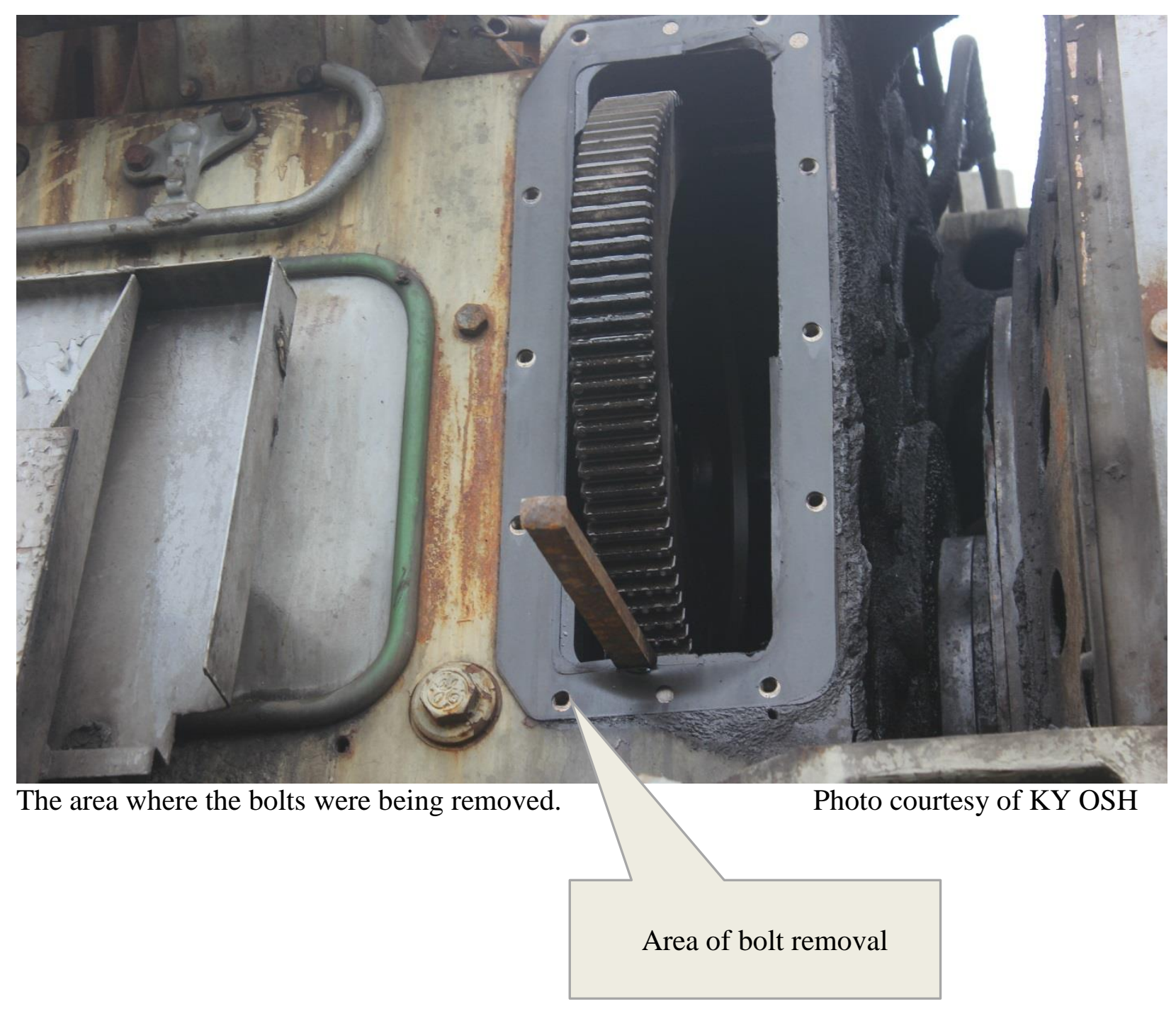




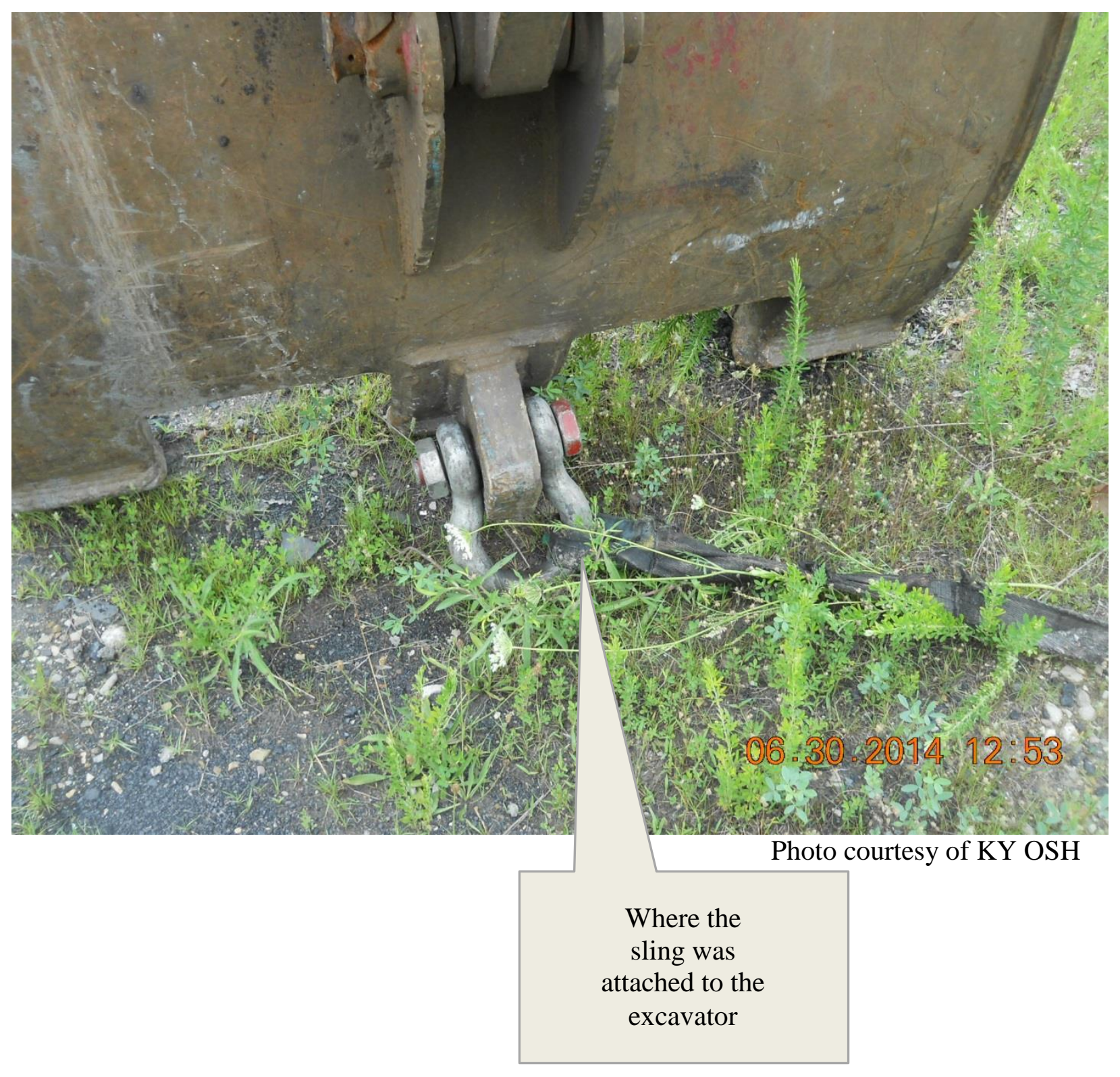

